
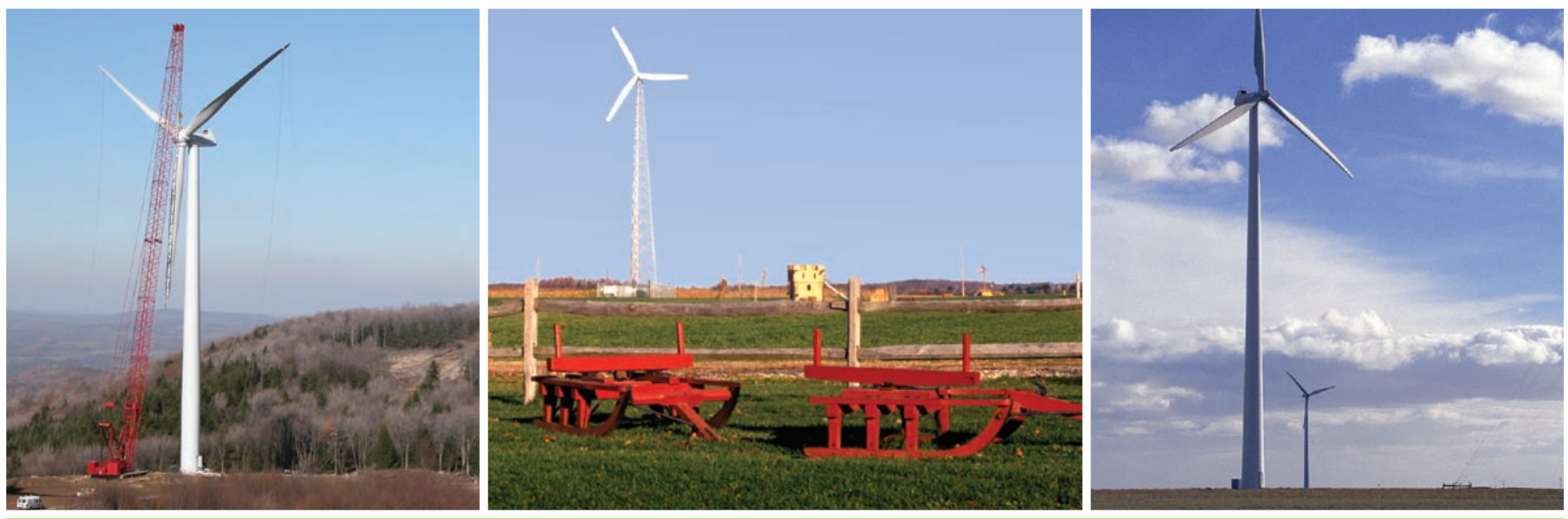

\title{
Wind Energy Guide for County Commissioners
}

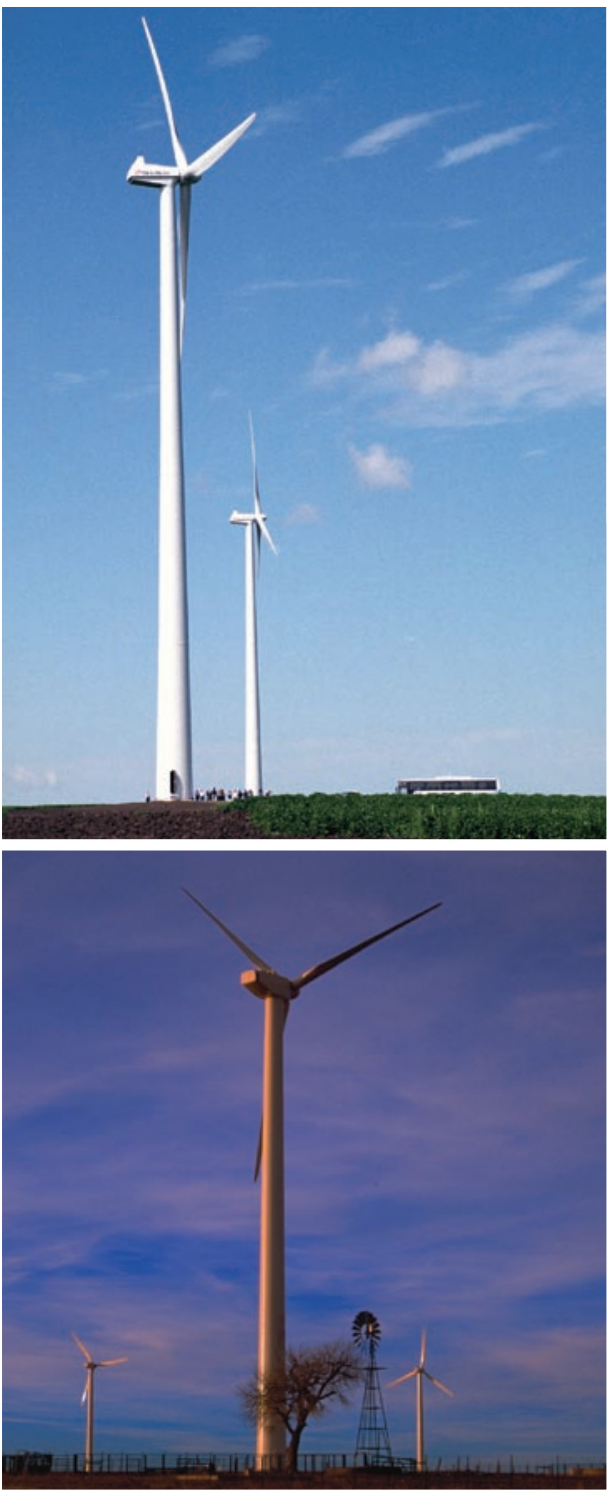

Project Team:

Mike Costanti

Peggy Beltrone

U.S. Department of Energy

National Renewable Energy Laboratory

Wind Powering America

National Association of Counties

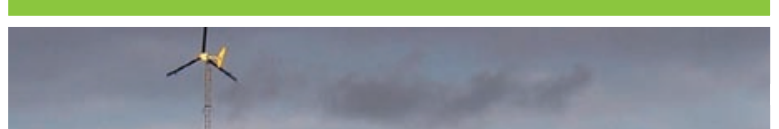

U.S. Department of Energy

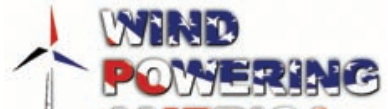
I AJ EDSGA
NA National Association of Counties

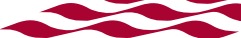

Counties Care for America 


\section{NOTICE}

This report was prepared as an account of work sponsored by an agency of the United States government. Neither the United States government nor any agency thereof, nor any of their employees, makes any warranty, express or implied, or assumes any legal liability or responsibility for the accuracy, completeness, or usefulness of any information, apparatus, product, or process disclosed, or represents that its use would not infringe privately owned rights. Reference herein to any specific commercial product, process, or service by trade name, trademark, manufacturer, or otherwise does not necessarily constitute or imply its endorsement, recommendation, or favoring by the United States government or any agency thereof. The views and opinions of authors expressed herein do not necessarily state or reflect those of the United States government or any agency thereof.

Available electronically at http://www.osti.gov/bridge

Available for a processing fee to U.S. Department of Energy and its contractors, in paper, from:

U.S. Department of Energy

Office of Scientific and Technical Information

P.O. Box 62

Oak Ridge, TN 37831-0062

phone: 865.576 .8401

fax: 865.576 .5728

email: mailto:reports@adonis.osti.gov

Available for sale to the public, in paper, from:

U.S. Department of Commerce

National Technical Information Service

5285 Port Royal Road

Springfield, VA 22161

phone: 800.553 .6847

fax: 703.605.6900

email: orders@ntis.fedworld.gov

online ordering: http://www.ntis.gov/ordering.htm 


\section{CONTENTS}

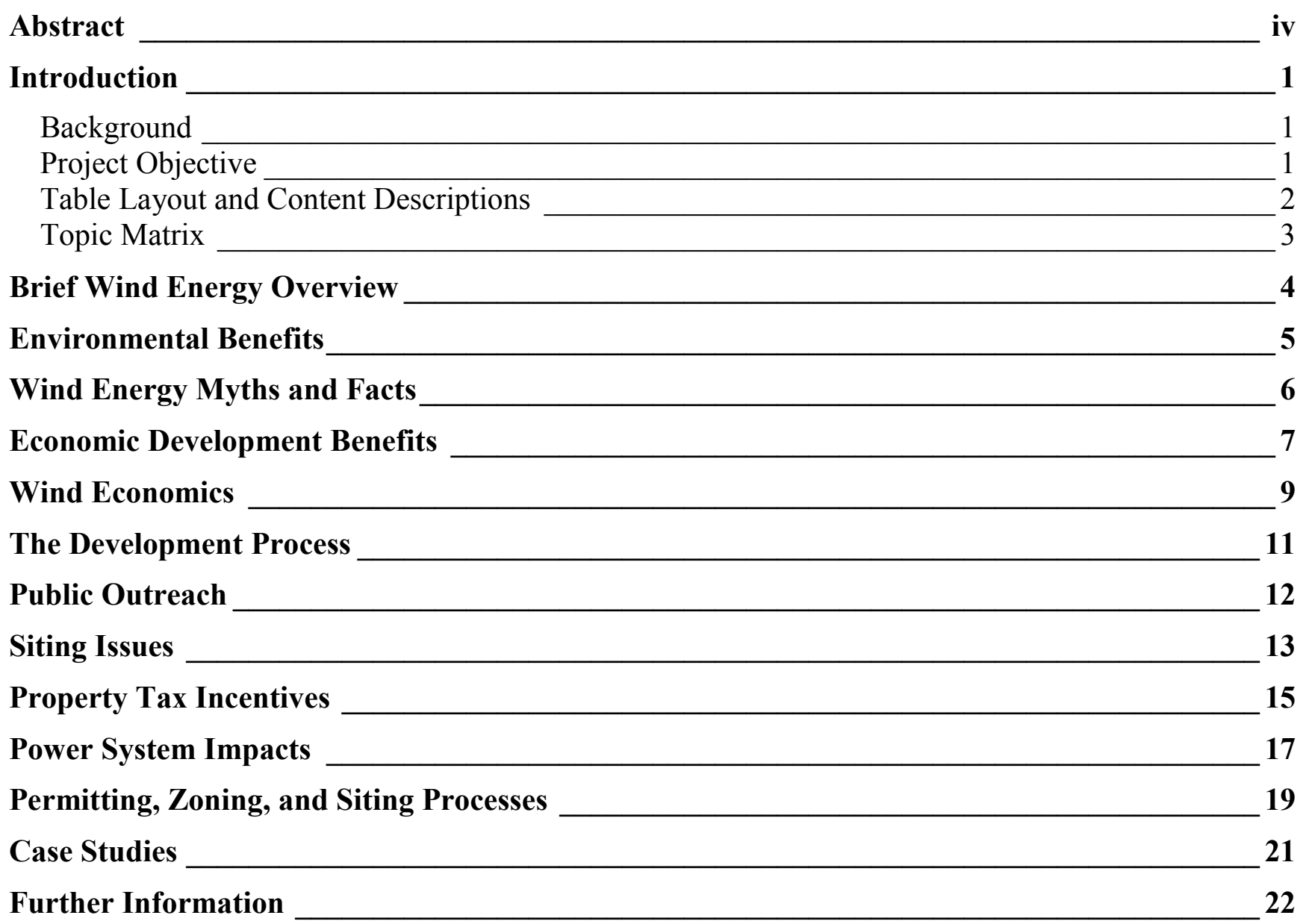




\begin{abstract}
One of the key stakeholders associated with economic development are local government officials, who are often required to evaluate and vote on commercial wind energy project permits, as well as to determine and articulate what wind energy benefits accrue to their counties. Often these local officials lack experience with large-scale wind energy and need to make important decisions concerning what may be a complicated and controversial issue. These decisions can be confounded with diverse perspectives from various stakeholders. This project is designed to provide county commissioners, planners, and other local county government officials with a practical overview of information required to successfully implement commercial wind energy projects in their county. The guidebook provides readers with information on the following 13 topics: Brief Wind Energy Overview; Environmental Benefits; Wind Energy Myths and Facts; Economic Development Benefits; Wind Economics; The Development Process; Public Outreach; Siting Issues; Property Tax Incentives; Power System Impacts; Permitting, Zoning, and Siting Processes; Case Studies; and Further Information. For each of the above topics, the guidebook provides an introduction that identifies the topic, why local government should care, a topic snapshot, how the topic will arise, and a list of resources that define and assess the topic.
\end{abstract}




\section{Introduction}

\section{Background}

Wind Powering America (WPA) is a U.S. Department of Energy (DOE) program to dramatically increase the use of wind energy in the United States. WPA's mission is to increase rural economic development, protect the environment, and increase energy security by engaging in state-based activities, rural economic development activities, the greening of federal loads, and collaborations with utilities.

WPA has established economic development as one of its primary thematic areas. A key stakeholder associated with economic development is local government officials, who often must evaluate and vote on commercial wind energy project permits, as well as determine and articulate the wind energy benefits that accrue to their county. These local officials often lack experience with large-scale wind energy but may need to make important decisions concerning projects. These decisions can be confounded with diverse perspectives from various stakeholders.

WPA is committed to providing the various stakeholders with valuable, accurate, and current information on wind energy. The use of stakeholder-tailored guidebooks has proven useful in this commitment, and accordingly the development of this guidebook will address many salient topics encountered by local government officials throughout the commercial wind development process.

\section{Project Objective}

This project is designed to provide county commissioners, planners, and other local county government officials with a practical overview of information required to successfully implement commercial, utility-scale wind energy projects (600 kilowatts or larger) in their counties. ${ }^{1}$

This guidebook provides a concise and practical resource for local government officials as they follow the steps to large-scale wind energy development. The guidebook is divided into the following 13 topics:

1. Brief Wind Energy Overview

2. Environmental Benefits

3. Wind Energy Myths and Facts

4. Economic Development Benefits

5. Wind Economics

6. The Development Process

7. Public Outreach

8. Siting Issues

9. Property Tax Incentives

10. Power System Impacts

11. Permitting, Zoning, and Siting Processes

12. Case Studies

13. Further Information.

\footnotetext{
${ }^{1}$ County commissioners are also actively involved with siting small (10 kilowatts or less) and medium-size (10 to 250 kilowatts) wind projects. Cultivating small projects and community wind projects can help build public support for a county's commercial wind marketing efforts. Visit http://www.windpoweringamerica.gov/small_wind.asp for more information on projects of this size.
} 
For each of the topics listed above, the guidebook provides an introduction that identifies the topic, why local government should care, an issue snapshot, how the topic will arise, and a list of resources that define and assess the topic. The following table layout is used for each topic.

Table Layout and Content Descriptions

\begin{tabular}{|c|c|c|}
\hline \multicolumn{2}{|c|}{ What Is It? } & Concise summary of the topic \\
\hline \multicolumn{2}{|c|}{ Why Should I Care? } & Indicates why the topic is important to local government officials \\
\hline \multicolumn{2}{|c|}{ Snapshot } & $\begin{array}{l}\text { Provides the reader with three to five key facts, recommendations, or } \\
\text { opinions outlined in the guidebook's Essential Resource list } \\
\text { - Snapshot \#1 } \\
\text { - Snapshot \#2 } \\
\text { - Snapshot \#3 }\end{array}$ \\
\hline \multicolumn{2}{|c|}{ When Will It Come Up? } & $\begin{array}{l}\text { From a local government official's point of view, the wind development } \\
\text { process can be broken down into seven distinctive phases, known as the } \\
\text { "7 P's": } \\
\text { 1. Potential: Investigating the basics of wind energy, as well as } \\
\text { establishing your county's wind resource } \\
\text { 2. Promotion: Promoting your county's wind resources to your } \\
\text { constituents and project developers } \\
\text { 3. Public Outreach: Engaging the public on wind energy topics } \\
\text { facing your county } \\
\text { 4. Planning: Creating and implementing an effective county plan to } \\
\text { facilitate wind energy development } \\
\text { 5. Permitting: Creating and implementing effective permitting, } \\
\text { zoning, and siting processes for wind energy projects within your } \\
\text { county } \\
\text { 6. Project Construction: Construction of the project takes place } \\
\text { 7. Project O\&M: Operations and maintenance (O\&M) of the } \\
\text { project takes place. } \\
\text { This section of the table will outline which of the } 7 \text { P's apply to the } \\
\text { topic. (The Topic Matrix following this table summarizes all } 13 \text { topics } \\
\text { and which of the } 7 \text { P's apply to each.) }\end{array}$ \\
\hline \multirow{2}{*}{ 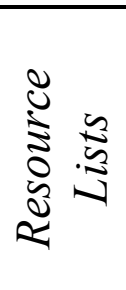 } & Essential & $\begin{array}{l}\text { Provides a list of resources that capture the essence of each respective } \\
\text { area. Resource title, location, brief summary }\end{array}$ \\
\hline & $\begin{array}{l}\text { Further } \\
\text { Reading }\end{array}$ & $\begin{array}{l}\text { Provides a list of resources for additional investigation. These resources } \\
\text { are typically available via the Internet. Resource title, location }\end{array}$ \\
\hline
\end{tabular}


Topic Matrix

\begin{tabular}{|c|c|c|c|c|c|c|c|c|}
\hline Topic & Description & Potential & Promotion & Outreach & Planning & Permitting & Construction & $O \& M$ \\
\hline $\begin{array}{l}\text { Brief Wind Energy } \\
\text { Overview }\end{array}$ & $\begin{array}{l}\text { Overview of wind energy basics, including } \\
\text { resource characteristics and technology }\end{array}$ & $\mathbf{X}$ & $\mathbf{X}$ & $\mathbf{X}$ & & & & \\
\hline $\begin{array}{l}\text { Environmental } \\
\text { Benefits }\end{array}$ & $\begin{array}{l}\text { Documentation of the environmental benefits of } \\
\text { wind power versus other electricity generation } \\
\text { alternatives }\end{array}$ & & $\mathbf{X}$ & $\mathbf{X}$ & $\mathbf{X}$ & $\mathbf{X}$ & $\mathbf{X}$ & $\mathbf{X}$ \\
\hline $\begin{array}{l}\text { Wind Energy Myths } \\
\text { and Facts }\end{array}$ & Description of key wind energy myths and facts & $\mathbf{X}$ & $\mathbf{X}$ & $\mathbf{X}$ & $\mathbf{X}$ & $\mathbf{X}$ & & \\
\hline $\begin{array}{l}\text { Economic } \\
\text { Development } \\
\text { Benefits }\end{array}$ & $\begin{array}{l}\text { Quantifies the economic development benefits } \\
\text { associated with wind energy projects }\end{array}$ & $\mathbf{X}$ & $\mathbf{X}$ & $\mathbf{X}$ & $\mathbf{X}$ & & $\mathbf{X}$ & $\mathbf{X}$ \\
\hline Wind Economics & $\begin{array}{l}\text { General information about the economics of wind } \\
\text { energy versus other generation sources }\end{array}$ & $\mathbf{X}$ & $\mathbf{X}$ & $\mathbf{X}$ & $\mathbf{X}$ & & & \\
\hline $\begin{array}{l}\text { The Development } \\
\text { Process }\end{array}$ & $\begin{array}{l}\text { Discussion of the typical commercial wind project } \\
\text { development steps }\end{array}$ & & & $\mathbf{X}$ & $\mathbf{X}$ & $\mathbf{X}$ & $\mathbf{X}$ & $\mathbf{X}$ \\
\hline Public Outreach & $\begin{array}{l}\text { Methods of facilitating public outreach with your } \\
\text { constituents }\end{array}$ & & $\mathbf{X}$ & $\mathbf{X}$ & $\mathbf{X}$ & $\mathbf{X}$ & $\mathbf{X}$ & $\mathbf{X}$ \\
\hline Siting Issues & $\begin{array}{l}\text { Overview of common siting impacts typically } \\
\text { associated with wind projects }\end{array}$ & & $\mathbf{X}$ & $\mathbf{X}$ & $\mathbf{X}$ & $\mathbf{X}$ & $\mathbf{X}$ & $\mathbf{X}$ \\
\hline $\begin{array}{l}\text { Property Tax } \\
\text { Incentives }\end{array}$ & $\begin{array}{l}\text { Discussion of what type of tax incentives are used } \\
\text { in commercial wind projects, as well as how to } \\
\text { effectively structure such incentives }\end{array}$ & & & $\mathbf{X}$ & $\mathbf{X}$ & $\mathbf{X}$ & $\mathbf{X}$ & $\mathbf{X}$ \\
\hline $\begin{array}{l}\text { Power System } \\
\text { Impacts }\end{array}$ & $\begin{array}{l}\text { Brief discussion of how wind projects are } \\
\text { integrated into the power system, including } \\
\text { integration with existing and future generation and } \\
\text { the transmission grid }\end{array}$ & & & $\mathbf{X}$ & $\mathbf{X}$ & $\mathbf{X}$ & $\mathbf{X}$ & $\mathbf{X}$ \\
\hline $\begin{array}{l}\text { Permitting, Zoning, } \\
\text { and Siting Processes }\end{array}$ & $\begin{array}{l}\text { Strategies for developing effective commercial } \\
\text { wind energy permitting processes and zoning } \\
\text { ordinances }\end{array}$ & & & $\mathbf{X}$ & $\mathbf{X}$ & $\mathbf{X}$ & $\mathbf{X}$ & $\mathbf{X}$ \\
\hline Case Studies & Description of successful wind project case studies & & $\mathbf{X}$ & $\mathbf{X}$ & & & & \\
\hline Further Information & $\begin{array}{l}\text { Additional information on topics not included in } \\
\text { the guidebook }\end{array}$ & & $\mathbf{X}$ & $\mathbf{X}$ & & & & \\
\hline
\end{tabular}




\section{Brief Wind Energy Overview}

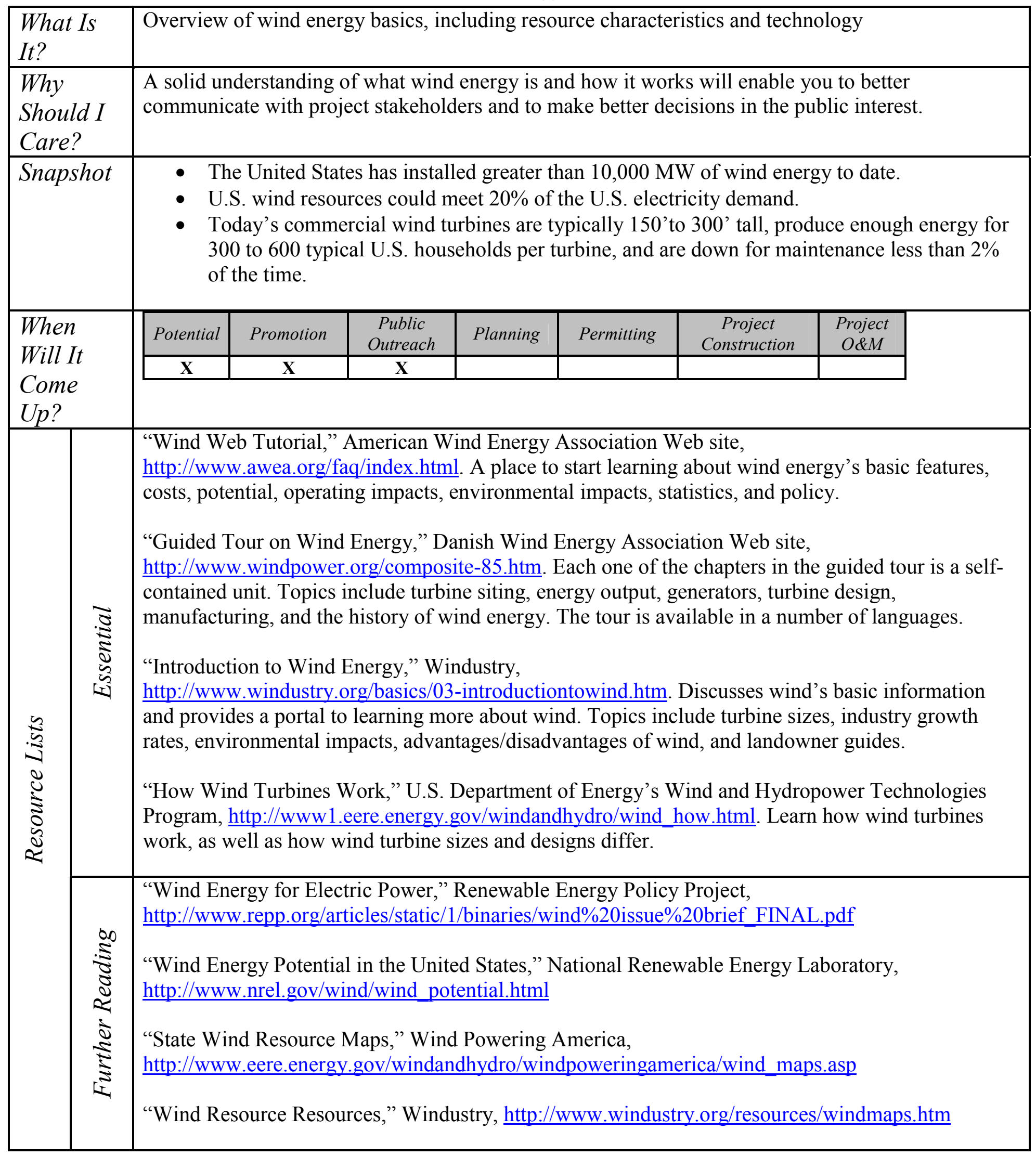




\section{Environmental Benefits}

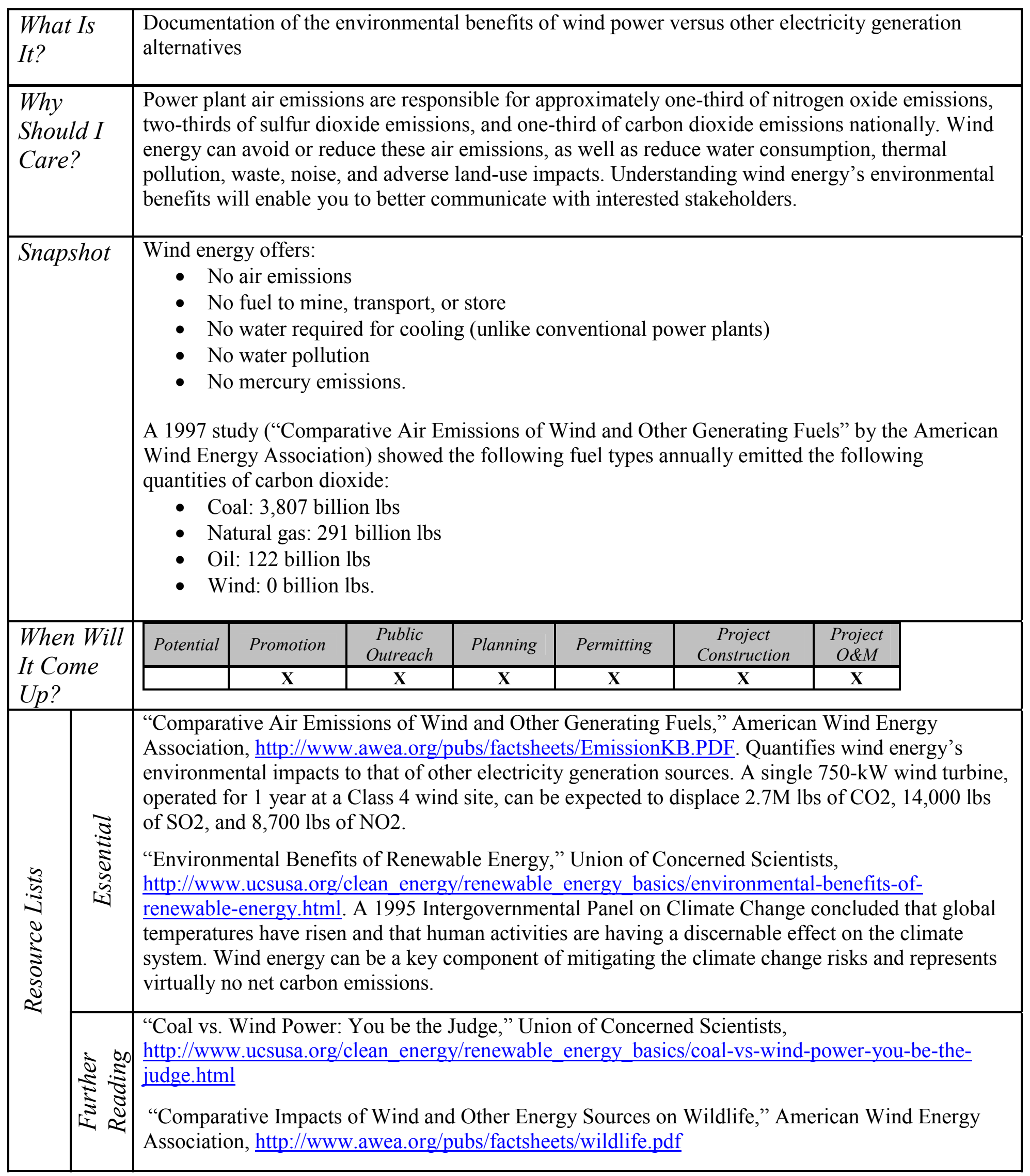


Wind Energy Myths and Facts

\begin{tabular}{|c|c|c|c|c|c|c|c|c|}
\hline \multicolumn{2}{|c|}{$\begin{array}{l}\text { What Is } \\
\text { It? }\end{array}$} & \multicolumn{7}{|c|}{ Description of key wind energy myths and facts } \\
\hline \multicolumn{2}{|c|}{$\begin{array}{l}\text { Why } \\
\text { Should I } \\
\text { Care? }\end{array}$} & \multicolumn{7}{|c|}{$\begin{array}{l}\text { Local government officials are typically an information source for a variety of stakeholders. This } \\
\text { section provides you with accurate information to distribute to your stakeholders and to use for } \\
\text { internal decision-making. }\end{array}$} \\
\hline \multicolumn{2}{|c|}{ Snapshot } & \multicolumn{7}{|c|}{$\begin{array}{l}\text { - An operating modern wind farm at a distance of } 750^{\prime}-1,000 \text { ' is no louder than a kitchen } \\
\text { refrigerator or moderately quiet room. } \\
\text { - Wind projects and wildlife can and do coexist successfully. } \\
\text { - Like all energy sources, wind energy receives federal and, in some cases, state subsidies. It } \\
\text { would be unfair to expect wind energy to compete in the marketplace without the incentives } \\
\text { enjoyed by traditional energy production methods. } \\
\text { - Wind energy does not require one-to-one generation backup as it is considered primarily an } \\
\text { energy resource. }\end{array}$} \\
\hline \multirow{2}{*}{\multicolumn{2}{|c|}{$\begin{array}{l}\text { When } \\
\text { Will It } \\
\text { Come } \\
\text { Up? }\end{array}$}} & Potential & Promotion & $\begin{array}{c}\text { Public } \\
\text { Outreach }\end{array}$ & Planning & ermitting & $\begin{array}{c}\text { Project } \\
\text { Construction } \\
\end{array}$ & $\begin{array}{c}\text { Project } \\
\text { O\&M } \\
\end{array}$ \\
\hline & & $\mathbf{X}$ & $\underline{X}$ & $\mathbf{X}$ & $\mathbf{X}$ & $\mathbf{X}$ & & \\
\hline \multirow[t]{2}{*}{ 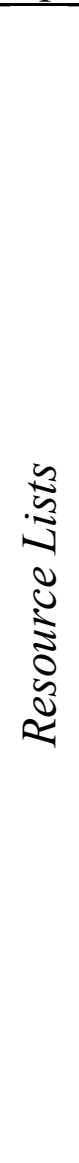 } & 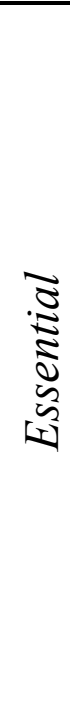 & \multicolumn{7}{|c|}{$\begin{array}{l}\text { "Wind Power Myths vs. Facts," American Wind Energy Association, } \\
\text { http://www.awea.org/pubs/factsheets/050629 Myths vs Facts Fact Sheet.pdf. As wind power } \\
\text { generates more electricity in the United States and moves into new areas of the country, more people } \\
\text { are introduced to wind turbines in their communities. Wind power is still a relatively new } \\
\text { technology and a number of myths - some based on old technologies, some based on } \\
\text { misunderstandings-are often repeated. This document uses facts from } 25 \text { years of utility experience } \\
\text { to dispel some of the most common wind power myths. Topics include noise, turbine lighting, } \\
\text { shadow flicker, communication signal interference, property values, tourism, tax base, safety, tower } \\
\text { failure, blade throws, wildlife impact, reliability, cost, availability, inefficiency, and subsidization. } \\
\text { "Wind Energy Myths," Wind Powering America, http://www.nrel.gov/docs/fy05osti/37657.pdf. } \\
\text { Discusses the } 10 \text { most common wind energy myths. Topics include cost, federal tax incentives, local } \\
\text { economic benefits, back-up generation, rate increases, system upgrades, power quality, small } \\
\text { projects, birds, and noise. }\end{array}$} \\
\hline & 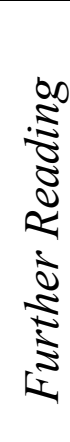 & $\begin{array}{l}\text { "If not wi } \\
\text { http://ww } \\
\text { "Update } \\
\text { Inc., http: } \\
\text { windandh } \\
\text { "Econom } \\
\text { http://ww }\end{array}$ & $\begin{array}{l}\mathrm{d} . . . \text { then wl } \\
\text {.ifnotwind. } \\
\text { Avian and } \\
\text { www.eere.e } \\
\text { dro/windpo } \\
\text { Impacts of } \\
\text { catenergy. }\end{array}$ & $\begin{array}{l}\text { t?", Amer } \\
\text { g/default.s } \\
\text { at Studies } \\
\text { ergy.gov/ } \\
\text { eringamer } \\
\text { Jind Powe } \\
\text { m/pdf } \% 2 \text { 2 }\end{array}$ & $\begin{array}{l}\text { in Wind } \mathrm{E} \\
\mathrm{ml} \\
\text { om Windp } \\
\text { adfs/wo } \\
\text { n Kittitas } \\
\text { les/Kittita }\end{array}$ & $\begin{array}{l}\text { rgy Associ } \\
\text { ver Studies } \\
\text { hops/2006 }\end{array}$ & $\begin{array}{l}\text { n, } \\
\text { Nestern Eco } \\
\text { mmit/kerns. } \\
\text { orthwest, } \\
\text { inal.pdf }\end{array}$ & tems Technology \\
\hline
\end{tabular}




\section{Economic Development Benefits}

\begin{tabular}{|c|c|c|c|c|c|c|c|c|}
\hline \multicolumn{2}{|c|}{$\begin{array}{l}\text { What Is } \\
\text { It? }\end{array}$} & \multicolumn{7}{|c|}{ Quantifies the economic development benefits associated with wind energy projects } \\
\hline \multicolumn{2}{|c|}{$\begin{array}{l}\text { Why } \\
\text { Should I } \\
\text { Care? }\end{array}$} & \multicolumn{7}{|c|}{$\begin{array}{l}\text { Wind energy projects are proven economic development drivers in the areas where they are sited. } \\
\text { This section will qualify and quantify the economic development benefits that can be expected. }\end{array}$} \\
\hline \multicolumn{2}{|c|}{ Snapshot } & \multicolumn{7}{|c|}{$\begin{array}{l}\text { - The main economic development benefits associated with wind projects are job creation, local } \\
\text { project spending, annual property and sales taxes, and annual landowner easement payments. } \\
\text { - Forty to } 140 \text { jobs are created during the construction phase for every } 100 \mathrm{MW} \text { of installed } \\
\text { capacity; } 6 \text { to } 10 \text { new jobs are created during the operations phase for every } 100 \mathrm{MW} \text { of } \\
\text { installed capacity. } \\
\text { - } \$ 500,000-\$ 1,000,000 \text { in new annual property tax payments are generated for every } 100 \mathrm{MW} \\
\text { of installed capacity. } \\
\text { - Annual landowner easement payments are typically } \$ 2,000-\$ 5,000 \text { per MW of installed } \\
\text { capacity. }\end{array}$} \\
\hline \multirow{2}{*}{\multicolumn{2}{|c|}{$\begin{array}{l}\text { When } \\
\text { Will It } \\
\text { Come } \\
\text { Up? }\end{array}$}} & Potential & Promotion & $\begin{array}{c}\text { Public } \\
\text { Outreach }\end{array}$ & Planning & Permitting & $\begin{array}{c}\text { Project } \\
\text { Construction }\end{array}$ & $\begin{array}{c}\text { Project } \\
O \& M\end{array}$ \\
\hline & & $\mathbf{X}$ & $\mathbf{X}$ & $\mathbf{X}$ & $\mathbf{X}$ & & $\mathbf{X}$ & $\bar{x}$ \\
\hline 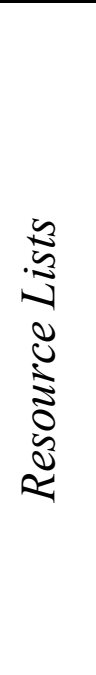 & 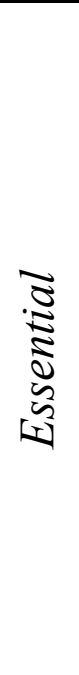 & \multicolumn{7}{|c|}{$\begin{array}{l}\text { "Wind Energy for Rural Economic Development," Wind Powering America, } \\
\text { http://www.eere.energy.gov/windandhydro/windpoweringamerica/pdfs/wpa/ } \\
\text { flowers windpower 2005.pdf. PowerPoint presentation that discusses economic development basics, } \\
\text { economic security, challenges, relationship with rural areas, and specific impacts, including job } \\
\text { creation, property taxes, and landowner revenues. Several case studies portray the real impacts wind } \\
\text { projects have had on local communities. } \\
\text { "Job and Economic Development Impact (JEDI) Model," National Renewable Energy Laboratory, } \\
\text { http://www.eere.energy.gov/windandhydro/windpoweringamerica/filter detail.asp?itemid=707. The } \\
\text { JEDI Model is an easy-to-use tool that analyzes the economic impacts of constructing and operating } \\
\text { wind power plants. Users enter basic project information to determine the project cost and the } \\
\text { income, economic activity, and number of jobs that will accrue to the state or local region. Using } \\
\text { project-specific data and an accurate estimate of the share of spending that is expected to occur } \\
\text { locally will result in a more accurate analysis of the localized impact. }\end{array}$} \\
\hline
\end{tabular}




\section{Economic Development Benefits, cont.}

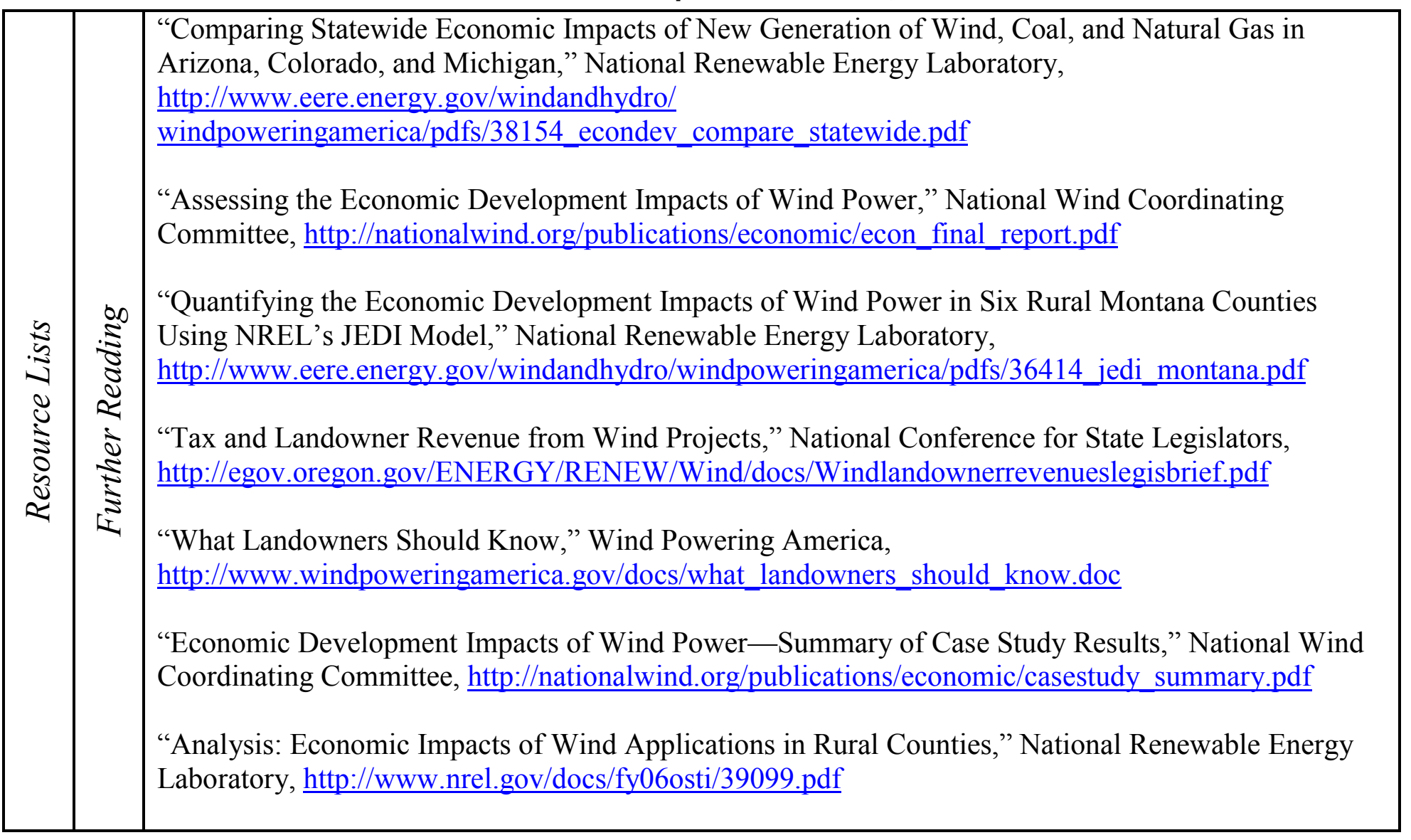


Wind Economics

\begin{tabular}{|c|c|c|c|c|c|c|c|c|}
\hline \multicolumn{2}{|c|}{$\begin{array}{l}\text { What Is } \\
\text { It? }\end{array}$} & \multicolumn{7}{|c|}{ General information about the economics of wind energy versus other generation sources } \\
\hline \multicolumn{2}{|c|}{\begin{tabular}{|l} 
Why \\
Should I \\
Care?
\end{tabular}} & \multicolumn{7}{|c|}{$\begin{array}{l}\text { Understanding the production costs of wind energy and other energy types will enable you to provide } \\
\text { accurate information to your stakeholders. }\end{array}$} \\
\hline \multicolumn{2}{|c|}{ Snapshot } & \multicolumn{7}{|c|}{$\begin{array}{l}\text { - Other energy generation types typically have an input fuel cost, whereas wind energy does } \\
\text { not. } \\
\text { - Conventional electricity generation options (excludes renewable sources) are often not } \\
\text { required to directly account for the societal costs of their environmental impacts. } \\
\text { - Wind energy's delivered cost has fallen } 90 \% \text { in the past } 25 \text { years and is now competitive with } \\
\text { other new generation sources (contract prices are typically } 4-6 \text { cents per kWh). } \\
\text { - Wind energy's economics are largely a function of the project's size, wind resource, policy } \\
\text { incentives, and financing. }\end{array}$} \\
\hline \multirow{2}{*}{\multicolumn{2}{|c|}{$\begin{array}{l}\text { When } \\
\text { Will It } \\
\text { Come } \\
\text { Up? }\end{array}$}} & Potential & Promotion & & Planning & rmitting & tion & \\
\hline & & $\underline{X}$ & $\underline{x}$ & $\mathbf{X}$ & $\bar{x}$ & & & \\
\hline $\begin{array}{l}0 \\
.3 \\
0 \\
0 \\
\vdots \\
0 \\
0 \\
2\end{array}$ & 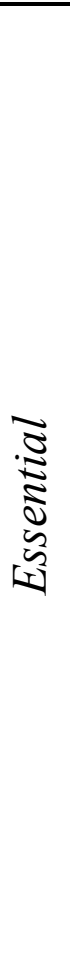 & \multicolumn{7}{|c|}{$\begin{array}{l}\text { "The Economics of Wind Energy," American Wind Energy Association, } \\
\text { http://www.awea.org/pubs/factsheets/EconomicsofWind-March2002.pdf. The economics of wind } \\
\text { energy have changed dramatically over the past } 20 \text { years, as the cost of wind power has fallen } ~ 90 \% \\
\text { during that period. Despite that progress, the wind industry is still maturing, with production volumes } \\
\text { increasing steadily. Thus, the factors affecting the cost of wind energy are still changing, and wind } \\
\text { energy's costs are expected to continue to decline as the industry grows and matures. Several topics } \\
\text { are discussed: cost and wind speed, improvements in turbine design, economies of scale, optimal } \\
\text { configuration of turbines, cost of financing, energy policy, and ancillary economic benefits. } \\
\text { "How Does Wind Compare to the Cost of Other Electricity Generation Options?", Wind Powering } \\
\text { America, } \\
\text { http://www.eere.energy.gov/windandhydro/windpoweringamerica/ne economics compare.asp. } \\
\text { In terms of direct costs, larger wind farms in windier areas are considered to be economically } \\
\text { competitive with new, conventional fossil fuel power plants. But to compare the costs of wind power } \\
\text { to other types of electricity generation on an apples-to-apples basis, it is critical to consider both } \\
\text { direct and indirect costs. Indirect costs are those that are imposed on society as a whole that are not } \\
\text { paid for by generators and therefore are not reflected in the direct costs of electricity. In comparing } \\
\text { the total costs of wind power with the costs of other alternatives, the costs of air, water, and land } \\
\text { pollution, as well as fuel extraction, supply lines, and military intervention to ensure supply must be } \\
\text { considered. }\end{array}$} \\
\hline
\end{tabular}




\section{Wind Economics, cont.}

\begin{tabular}{|c|c|c|}
\hline & & $\begin{array}{l}\text { "Wind Energy Economics," Windustry, http://www.windustry.org/basics/07-economics.htm } \\
\text { "What are the factors in the cost of electricity from wind turbines?", AWEA, } \\
\text { http://www.awea.org/faq/cost.html }\end{array}$ \\
\hline & 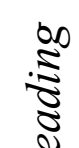 & $\begin{array}{l}\text { "Wind Energy for Electric Power-A REPP Issue Brief," Renewable Energy Policy Project, } \\
\text { http://www.repp.org/articles/static/1/binaries/wind\%20issue\%20brief_FINAL.pdf }\end{array}$ \\
\hline & $\frac{\sqrt[3]{3}}{\sqrt[3]{2}}$ & $\begin{array}{l}\text { “Colorado Public Utility Commission's Xcel Wind Decision," National Renewable Energy Laboratory, } \\
\text { http://www.nrel.gov/docs/fy01osti/30551.pdf }\end{array}$ \\
\hline & & $\begin{array}{l}\text { "Federal Energy Subsidies—Not all Technologies are Created Equal," Renewable Energy Policy } \\
\text { Project, http://www.crest.org/repp pubs/pdf/subsidies.pdf }\end{array}$ \\
\hline & & $\begin{array}{l}\text { Vind, } \\
\text { vorkshops/2006 summit/vaughan.pdf }\end{array}$ \\
\hline
\end{tabular}


The Development Process

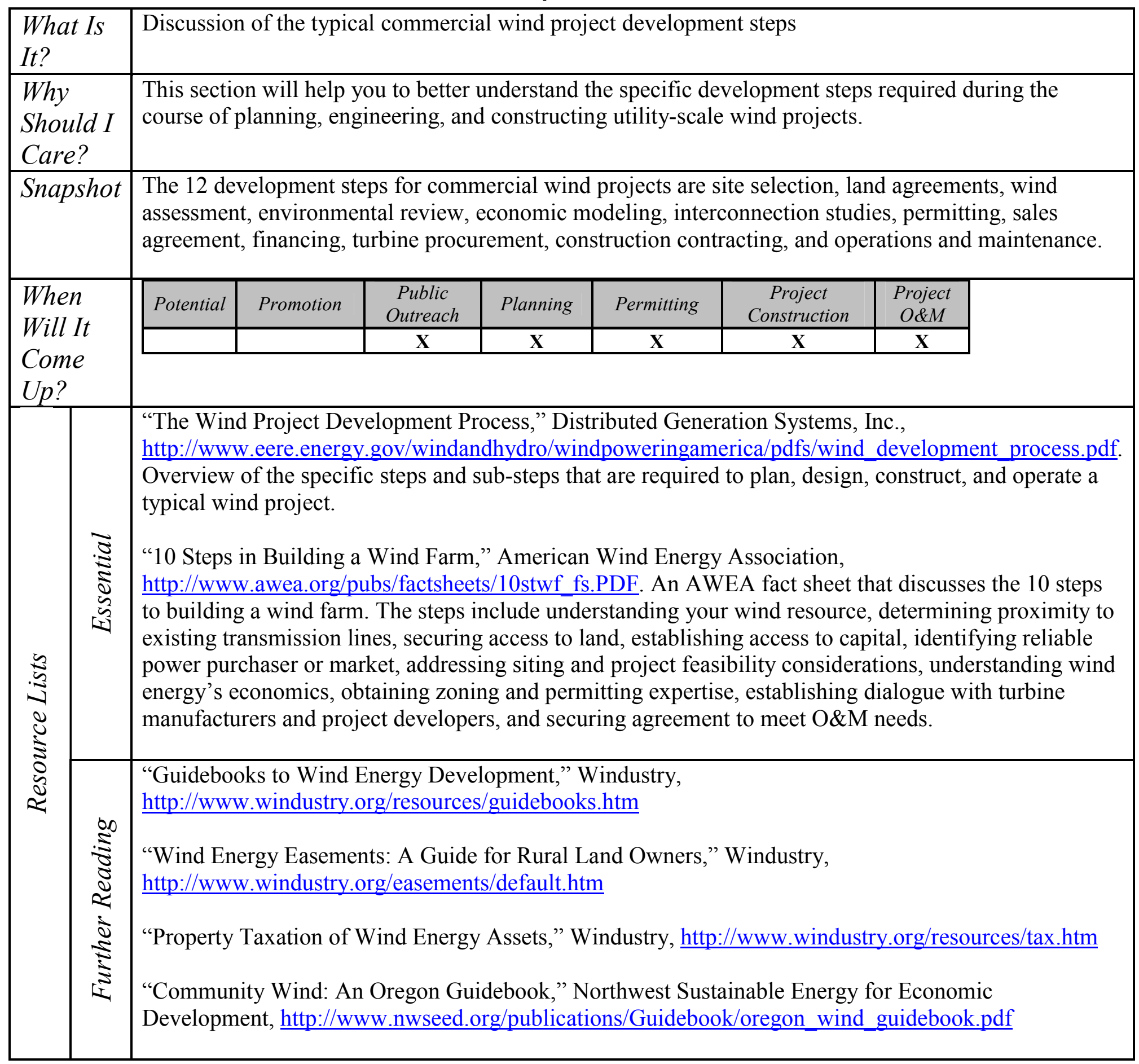




\section{Public Outreach}

\begin{tabular}{|c|c|c|c|c|c|c|c|c|}
\hline \multicolumn{2}{|c|}{$\begin{array}{l}\text { What Is } \\
\text { It? }\end{array}$} & \multicolumn{7}{|c|}{ Methods of facilitating public outreach with your constituents } \\
\hline \multicolumn{2}{|c|}{$\begin{array}{l}\text { Why } \\
\text { Should I } \\
\text { Care? }\end{array}$} & \multicolumn{7}{|c|}{$\begin{array}{l}\text { As a local government official, communication during the development and operation of any project } \\
\text { is critical. This section will provide you with effective strategies for communicating with project } \\
\text { stakeholders during the planning, construction, and operation phases. }\end{array}$} \\
\hline \multicolumn{2}{|c|}{ Snapshot } & \multicolumn{7}{|c|}{$\begin{array}{l}\text { - Public involvement is always worthwhile and public workshops are crucial. } \\
\text { - Listen carefully to community concerns and gather information as needed. } \\
\text { - Effective messages contain three key topics: } \\
\text { - Begin with the most important item first. } \\
\text { - Talk in } 30 \text {-second sound bites. } \\
\text { - Avoid reading a script. } \\
\text { - Be prompt when following up with media requests for information. }\end{array}$} \\
\hline \multirow{2}{*}{\multicolumn{2}{|c|}{$\begin{array}{l}\text { When } \\
\text { Will It } \\
\text { Come } \\
\text { Up? }\end{array}$}} & Potential & Promotion & $\begin{array}{c}\text { Public } \\
\text { Outreach }\end{array}$ & Planning & Permitting & $\begin{array}{c}\text { Project } \\
\text { Construction } \\
\end{array}$ & $\begin{array}{l}\text { Project } \\
O \& M \\
\end{array}$ \\
\hline & & & $\mathbf{X}$ & $\mathrm{X}$ & $\mathbf{X}$ & $\mathrm{X}$ & $\mathbf{X}$ & $\underline{X}$ \\
\hline \multirow[t]{2}{*}{ 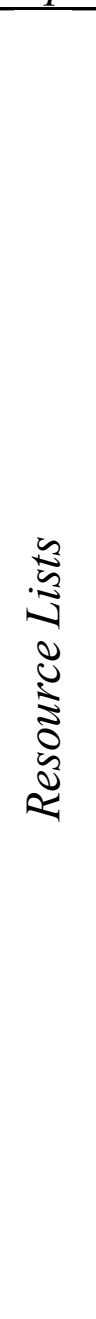 } & 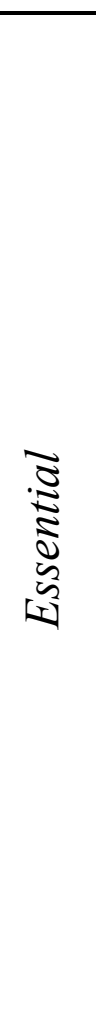 & \multicolumn{7}{|c|}{$\begin{array}{l}\text { "Working with the Farm Broadcasters and the Broadcast Media," Michelle Rook, } \\
\text { http://www.eere.energy.gov/windandhydro/windpoweringamerica/ } \\
\text { pdfs/workshops/2005 summit/rook.pdf. Presentation at the } 2005 \text { WPA State Summit that discusses } \\
\text { general rules for working with broadcasters and reporters, how farm broadcasters differ from } \\
\text { mainstream reporters, and tips for packaging your message. Rook also covers characteristics of good } \\
\text { interviews and tips for handling tough interviews. } \\
\text { "Wind Power Facility Siting Case Studies: Community Response," National Wind Coordinating } \\
\text { Committee, } \\
\text { http://nationalwind.org/publications/siting/Wind_Power_Facility_Siting_Case_Studies.pdf. } \\
\text { The NWCC Siting Workgroup studied communities' reactions to local wind development projects, } \\
\text { with the intent of identifying circumstances that distinguish welcomed projects from projects that } \\
\text { were resisted by the communities. The NWCC Siting Workgroup was also interested in examining } \\
\text { the changes in community perceptions before, during, and after project construction, as well as } \\
\text { recognizing what wind project developers can do to address the common concerns that often occur at } \\
\text { wind project sites. Case studies are presented from southwestern Minnesota, central New York, and } \\
\text { south central/western Oklahoma. The interviews and background research identified many aspects of } \\
\text { a successful partnership among wind developers, local communities, governments, and other } \\
\text { concerned parties. The following approaches were used by developers to successfully deal with } \\
\text { community concerns: listen carefully to community concerns, educate the public, communicate early } \\
\text { and often, and remain open to unorthodox solutions. }\end{array}$} \\
\hline & & \multicolumn{7}{|c|}{$\begin{array}{l}\text { "Permitting of Wind Energy Facilities—a Handbook," National Wind Coordinatir } \\
\text { http://nationalwind.org/publications/siting/permitting2002.pdf } \\
\text { "Sample Introductory Letter to Neighbors," American Wind Energy Association, } \\
\text { http://www.awea.org/smallwind/toolbox/SAMPLE LETTERS/default.asp }\end{array}$} \\
\hline
\end{tabular}


Siting Issues

\begin{tabular}{|c|c|c|c|c|c|c|c|c|c|}
\hline \multicolumn{2}{|c|}{$\begin{array}{l}\text { What Is } \\
\text { It? }\end{array}$} & \multicolumn{8}{|c|}{ Overview of common siting issues typically associated with wind projects } \\
\hline \multicolumn{2}{|c|}{$\begin{array}{l}\text { Why } \\
\text { Should I } \\
\text { Care? }\end{array}$} & \multicolumn{8}{|c|}{$\begin{array}{l}\text { Siting issues typically draw intense public scrutiny. This section provides accurate information and } \\
\text { analysis of the most common wind energy siting issues. }\end{array}$} \\
\hline \multicolumn{2}{|c|}{ Snapshot } & \multicolumn{8}{|c|}{$\begin{array}{l}\text { - The large majority of wind energy siting issues can be mitigated via effective public } \\
\text { communication by directly addressing pertinent siting issues raised by the public and } \\
\text { implementing effective siting guidelines. } \\
\text { - The following estimated annual avian collision mortalities occur in the United States: } \\
\text { - Vehicles: } 60-80 \text { million } \\
\text { - Buildings/windows: } 98-980 \text { million } \\
\text { - Transmission lines: } 174 \text { million } \\
\text { - Communication towers: } 4-50 \text { million } \\
\text { - Wind turbines: } 0.01-0.04 \text { million } \\
\text { - Research shows that wind projects do not have detrimental effects on tourism or property } \\
\text { values and that turbine noise is minimal. }\end{array}$} \\
\hline \multirow{2}{*}{\multicolumn{2}{|c|}{$\begin{array}{l}\text { When Will } \\
\text { It Come } \\
\text { Up? }\end{array}$}} & Potential & Promotion & $\begin{array}{c}\text { Public } \\
\text { Outreach } \\
\end{array}$ & Planning & Permitting & $\begin{array}{l}\text { Project } \\
\text { onstruction }\end{array}$ & $O \& M$ & \\
\hline & & & $\mathbf{X}$ & $\mathbf{X}$ & $\mathbf{X}$ & $\mathbf{X}$ & $\mathbf{X}$ & $\mathbf{X}$ & \\
\hline 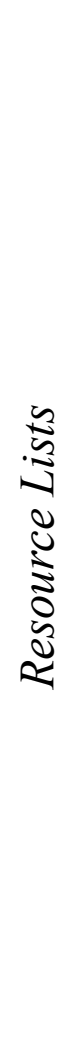 & 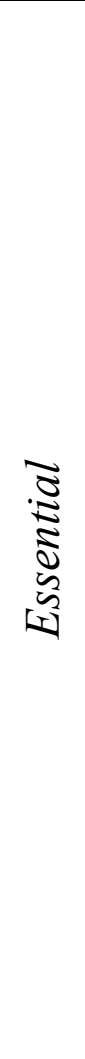 & \multicolumn{8}{|c|}{$\begin{array}{l}\text { "The Effects of Wind Development on Local Property Values," Renewable Energy Policy Project } \\
\text { http://www.repp.org/articles/static/1/binaries/wind online final.pdf. The report reviews data on } \\
\text { property sales in the vicinity of wind projects and uses statistical analysis to determine whether and } \\
\text { the extent to which the presence of a wind power project has influenced property prices. The } \\
\text { hypothesis underlying this analysis is that if wind development can reasonably be claimed to hurt } \\
\text { property values, then a careful review of the sales data should show a negative effect on property } \\
\text { values with the viewshed of the projects. The results suggest that there is no support for the claim } \\
\text { that wind development will harm property values. } \\
\text { "Facts About Wind Energy and Noise," American Wind Energy Association, } \\
\text { http://www.awea.org/pubs/factsheets/WE Noise.pdf. The fact sheet discusses noise, the types of } \\
\text { noise produced by wind turbines and wind farms, and how manufacturers reduce wind turbine noise. } \\
\text { Additionally, a brief discussion on how to reduce the likelihood of a noise problem from a wind } \\
\text { project is included. } \\
\text { "Avian Collisions with Wind Turbines: A Summary of Existing Studies and Comparisons of Avian } \\
\text { Collision Mortality in the United States," National Wind Coordinating Committee, } \\
\text { http://www.nationalwind.org/publications/wildlife/avian collisions.pdf. Reports the estimated } \\
\text { number of avian collision mortality in the United States, typical causes of avian mortality, and risks } \\
\text { to avian populations from wind projects. Based on current estimates, avian fatalities related to wind } \\
\text { farms represent from 0.01\% to 0.02\% (i.e., 1 out of every 5,000 to 10,000 avian fatalities) of the } \\
\text { annual avian collision fatalities in the United States. }\end{array}$} \\
\hline
\end{tabular}


Siting Issues, cont.

\begin{tabular}{|c|c|c|}
\hline 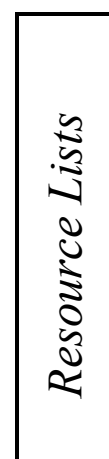 & 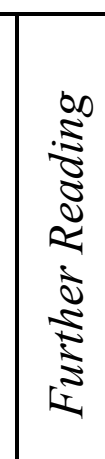 & $\begin{array}{l}\text { "Wind Radar Interference," Idaho National Laboratory, } \\
\text { http://www.eere.energy.gov/windandhydro/windpoweringamerica/pdfs/ } \\
\text { workshops/2006 summit/seifert.pdf } \\
\text { "Tourist Attitudes Towards Wind Farms," British Wind Energy Association, } \\
\text { http://www.bwea.com/pdf/MORI.pdf } \\
\text { "Aesthetic Issues and Residential Wind Turbines," American Wind Energy Association, } \\
\text { http://www.awea.org/faq/sagrillo/ms_aesthetics_0405.html }\end{array}$ \\
\hline
\end{tabular}




\section{Property Tax Incentives}

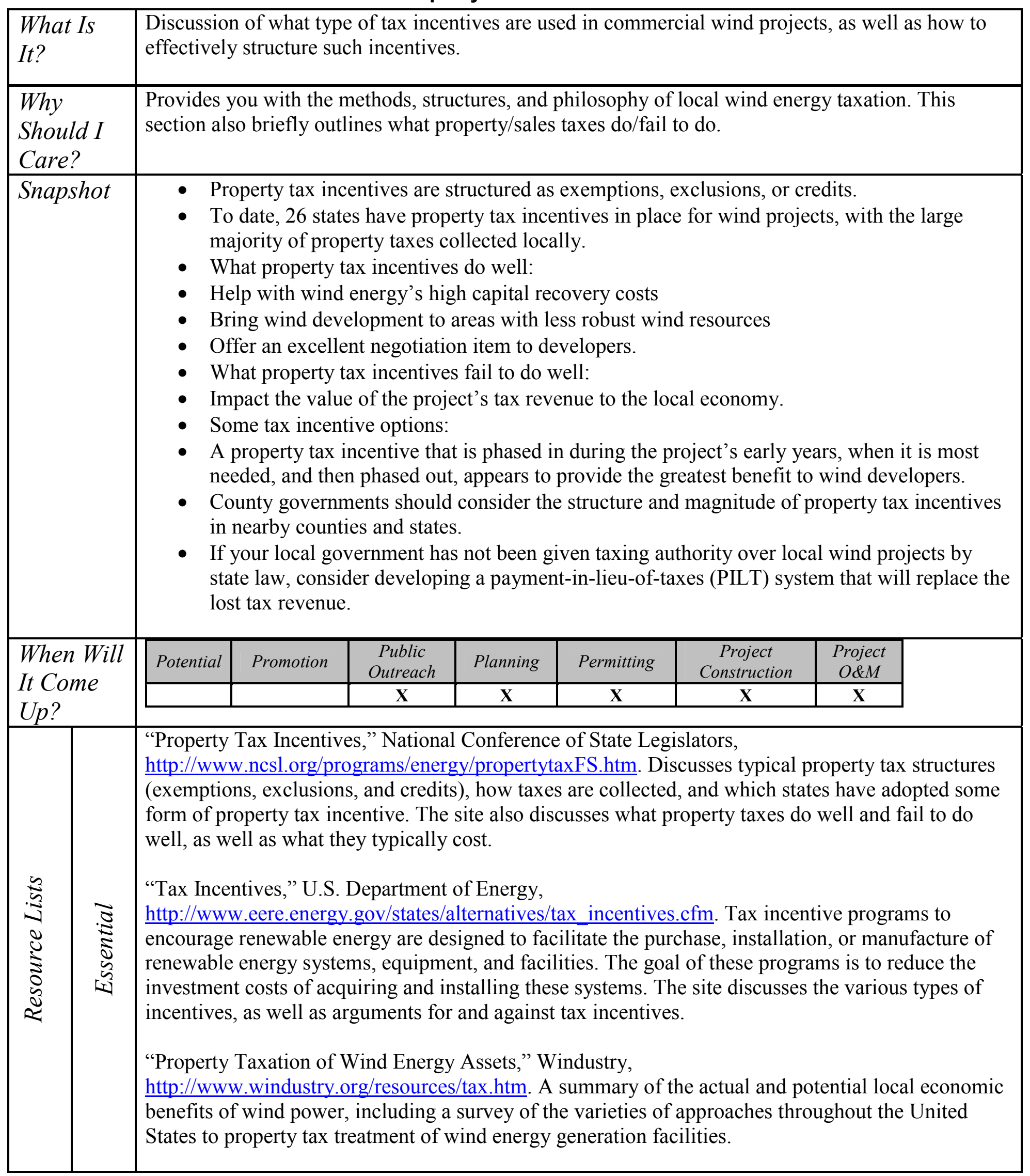




\section{Property Tax Incentives, cont.}

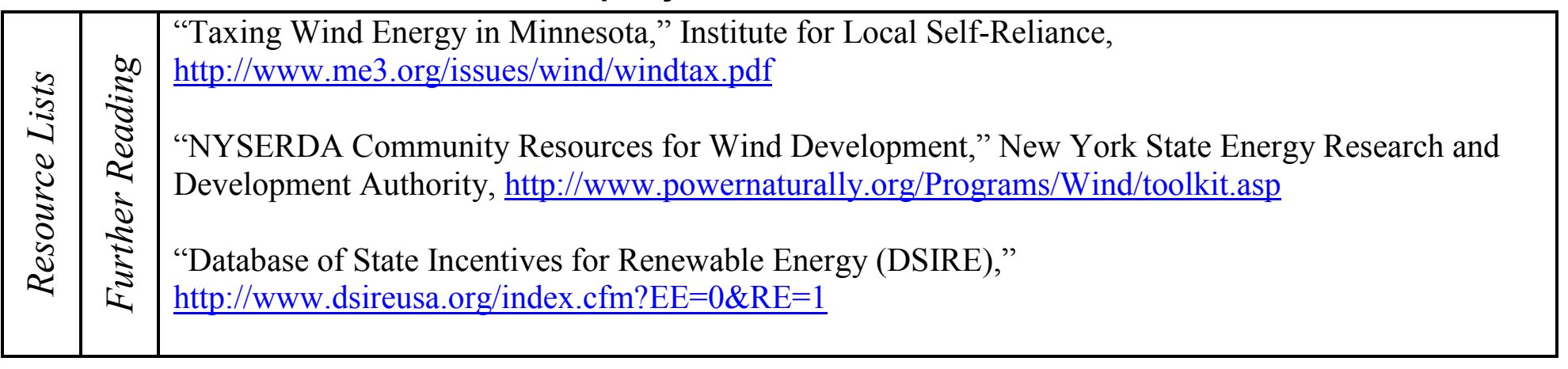


Power System Impacts

\begin{tabular}{|c|c|c|c|c|c|c|c|c|}
\hline $\begin{array}{l}\text { Wha } \\
\text { It? }\end{array}$ & & $\begin{array}{l}\text { Brief disc } \\
\text { with exist }\end{array}$ & $\begin{array}{l}\text { ion of hor } \\
\text { and futur }\end{array}$ & ind pro & $\begin{array}{l}\text { are int } \\
d \text { the tr }\end{array}$ & $\begin{array}{l}\text { d into tl } \\
\text { ssion gl }\end{array}$ & r syste & ding integration \\
\hline $\begin{array}{l}\text { Why } \\
\text { Shor } \\
\text { Care }\end{array}$ & & $\begin{array}{l}\text { Integratin } \\
\text { and proce } \\
\text { with proje }\end{array}$ & $\begin{array}{l}\text { vind energ } \\
\text { ral topic. } 7 \\
\text { stakehold }\end{array}$ & $\begin{array}{l}\text { vith existi } \\
\text { section } 1\end{array}$ & $\begin{array}{l}\text { transmi } \\
\text { jides y }\end{array}$ & $\begin{array}{l}\text { and ge } \\
\text { th the } n\end{array}$ & $\begin{array}{l}\text { n system } \\
\text { y inform }\end{array}$ & $\begin{array}{l}\text { omplex technical } \\
\text { o discuss the topic }\end{array}$ \\
\hline Snap & & $\begin{array}{l}\text { - In } \\
\text { m } \\
\text { th } \\
\text { - } \mathrm{U} \\
\mathrm{pe} \\
\text { its } \\
\text { an } \\
\text { - } \mathrm{Tl} \\
\text { ba } \\
\text { - } \mathrm{Fr} \\
\mathrm{pl} \\
\text { sy } \\
\text { - } \\
\text { tra } \\
\text { en } \\
\text { ce } \\
\text { co }\end{array}$ & $\begin{array}{l}\text { eas with li } \\
\text { ern wind } p \\
\text { increase s. } \\
\text { ty planner } \\
\text { demand. I } \\
\text { ility to dis } \\
\text { emission ri } \\
\text { addition of } \\
\text { up, as win } \\
\text { tioning ho } \\
\text { variability } \\
\text { m capacit } \\
\text { d energy's } \\
\text { mission se } \\
\text { gy into the } \\
\text { per } k W h . \\
\text { ol-area sp }\end{array}$ & $\begin{array}{l}\text { ed penetr } \\
\text { ts can be } \\
\text { m perfor } \\
\text { aditionall } \\
\text { vever, wi } \\
\text { ce more } \\
\text { wind plan } \\
\text { used pri } \\
\text { ahead an } \\
\text { nd few of } \\
\text { iability is } \\
\text { ce provid } \\
\text { xisting tr } \\
\text { irrently, } \\
\text { ic. }\end{array}$ & $\begin{array}{l}\text { on (less t } \\
\text { ded with } \\
\text { nce). } \\
\text { iew new } \\
\text { is prima } \\
\text { ensive e } \\
\text { a powe } \\
\text { ily as an } \\
\text { ay-ahead } \\
\text { ating im! } \\
\text { t a critic } \\
\text { have ad } \\
\text { mission } \\
\text { eling fee }\end{array}$ & $\begin{array}{l}10 \%) \text {, sys } \\
\text { degrading } \\
\text { eration pr } \\
\text { an energy } \\
\text { sy and to } s \\
\text { stem does } \\
\text { ergy resou } \\
\text { rkets prov } \\
\text { s occur wl } \\
\text { ransmissic } \\
\text { d effectiv } \\
\text { ems at op } \\
\text { mbalance }\end{array}$ & $\begin{array}{l}\text { stabilities } \\
\text { em perform } \\
\text { ily in terms } \\
\text { urce, mean } \\
\text { as a hedge } \\
\text { require the } \\
\text { he best me } \\
\text { wind repres } \\
\text { tegration is } \\
\text { ocedures fo } \\
\text { ng impact c } \\
\text { lties, and c }\end{array}$ & $\begin{array}{l}\text { es have shown that } \\
\text { e and in many cases } \\
\text { its capacity to serve } \\
\text { that its value lies in } \\
\text { inst future fuel price } \\
\text { tion of a one-to-one } \\
\text { of addressing wind } \\
\text { less than } 15 \% \text { of the } \\
\text { and many } \\
\text { egrating wind } \\
\text { of less than } 0.5 \\
\text { ity valuations are }\end{array}$ \\
\hline Whe & & Potential & romotion & $\begin{array}{c}\text { Public } \\
\text { Outreach }\end{array}$ & Planning & ermitting & $\begin{array}{c}\text { Project } \\
\text { Construction }\end{array}$ & $\begin{array}{c}\text { Project } \\
O \& M \\
\end{array}$ \\
\hline $\begin{array}{l}\text { It C } \\
U p ?\end{array}$ & & & & $\mathbf{X}$ & $\underline{X}$ & $\bar{x}$ & $\mathbf{X}$ & $\mathbf{x}$ \\
\hline 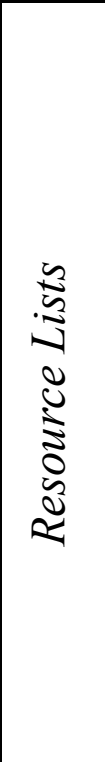 & 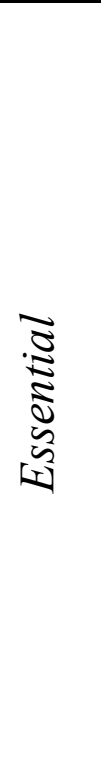 & $\begin{array}{l}\text { "Utility V } \\
\text { http://ww } \\
\text { costs attri } \\
\text { interconn } \\
\text { wind in th } \\
\text { Engineers } \\
\text { "Distribu } \\
\text { Energy M } \\
\text { windandh } \\
\text { to determ } \\
\text { northeast } \\
\text { study, anc } \\
\text { were eval } \\
\text { wind gen } \\
\text { within } 5 \text { r }\end{array}$ & $\begin{array}{l}\text { d Integrat } \\
\text { uwig.org/L } \\
\text { ted to inco } \\
\text { ion, integr } \\
\text { future. Stu } \\
\text { d the Pow } \\
\text { Wind Ge1 } \\
\text { agement a } \\
\text { ro/windpo } \\
\text { the ability } \\
\text { Colorado } \\
\text { ne HEA pr } \\
\text { ted using t } \\
\text { tion added } \\
\text { es of an ex }\end{array}$ & $\begin{array}{l}\text { n State of t } \\
\text { VIGWindI } \\
\text { orating sig } \\
\text { ion, transm } \\
\text { performe } \\
\text { Engineeri } \\
\text { ration Stuc } \\
\text { a Wind Po } \\
\text { eringameri } \\
\text { o intercon } \\
\text { he Highlir } \\
\text { ided the d } \\
\text { existing d } \\
\text { vas in the r } \\
\text { ting substa }\end{array}$ & $\begin{array}{l}\text { Art," Ut } \\
\text { egration0 } \\
\text { ificant wi } \\
\text { sion plan } \\
\text { in conjun } \\
\text { g Society. } \\
\text { for North } \\
\text { ering Ame } \\
\text { /filter_de } \\
\text { ct large w } \\
\text { Electric } \\
\text { ign and o } \\
\text { tribution } \\
\text { ge of one } \\
\text { on. }\end{array}$ & $\begin{array}{l}\text { Wind In } \\
06 . p d f . ~ \\
\text { eneratio } \\
\text { and ma } \\
\text { t with In } \\
\text { Colorad } \\
\text { http://v } \\
\text { turp?item } \\
\text { turbines } \\
\text { ciation's } \\
\text { ting data } \\
\text { em and v } \\
\text { five winc }\end{array}$ & $\begin{array}{l}\text { tion Group } \\
\text { summary s } \\
\text { the power } \\
\text { peration, } \\
\text { of Electri } \\
\text { olorado G } \\
\text { ere.energ } \\
\text { O999. The p } \\
\text { ypical dist } \\
\text { A) distribu } \\
\text { s electric } s \\
\text { ound to be } \\
\text { ines at a pa }\end{array}$ & $\begin{array}{l}\text { ing system impact } \\
\text { em. Topics include } \\
\text { ccommodating more } \\
\text { nd Electronic } \\
\text { or's Office of } \\
\text { se of the study was } \\
\text { ion system in } \\
\text { grid was used for the } \\
\text { n. Three scenarios } \\
\text { tical if the amount of } \\
\text { lar location or area, }\end{array}$ \\
\hline
\end{tabular}


Power System Impacts, cont.

\begin{tabular}{|c|c|c|}
\hline \multirow{7}{*}{ 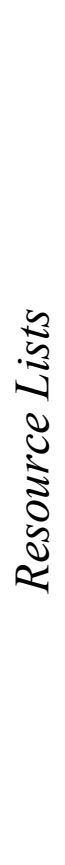 } & \multirow{7}{*}{ 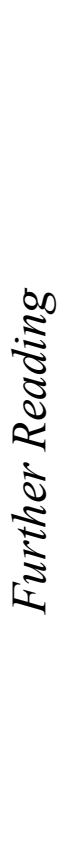 } & $\begin{array}{l}\text { "Wind Power Impacts on System Operation: A Summary of Results," Utility Wind Interest Group, } \\
\text { https://www.nationalwind.org/events/business/31/presentations/smith.pdf }\end{array}$ \\
\hline & & $\begin{array}{l}\text { "Utility Integration of Wind Power," Renewable Northwest Project, } \\
\text { http://www.rnp.org/Resources/WindIntegration.html }\end{array}$ \\
\hline & & "Wind Energy Interconnection," National Wind Coordinating Committee, \\
\hline & & \\
\hline & & $\begin{array}{l}\text { "Fair Transmission Access for Wind: A Brief Discussion of Priority Issues," American Wind Energy } \\
\text { Association, http://www.awea.org/policy/documents/transmission.PDF }\end{array}$ \\
\hline & & $\begin{array}{l}\text { "Analyses of Wind Energy Impact on WFEC System Operations," National Renewable Energy } \\
\text { Laboratory, http://www.nrel.gov/docs/fy05osti/37851.pdf }\end{array}$ \\
\hline & & $\begin{array}{l}\text { "The Effects of Integrating Wind Power on Transmission System Planning, Reliability, and } \\
\text { Operations," New York State Energy Research and Developmental Authority, } \\
\text { http://www.nyserda.org/publications/wind_integration_report.pdf }\end{array}$ \\
\hline
\end{tabular}




\section{Permitting, Zoning, and Siting Processes}

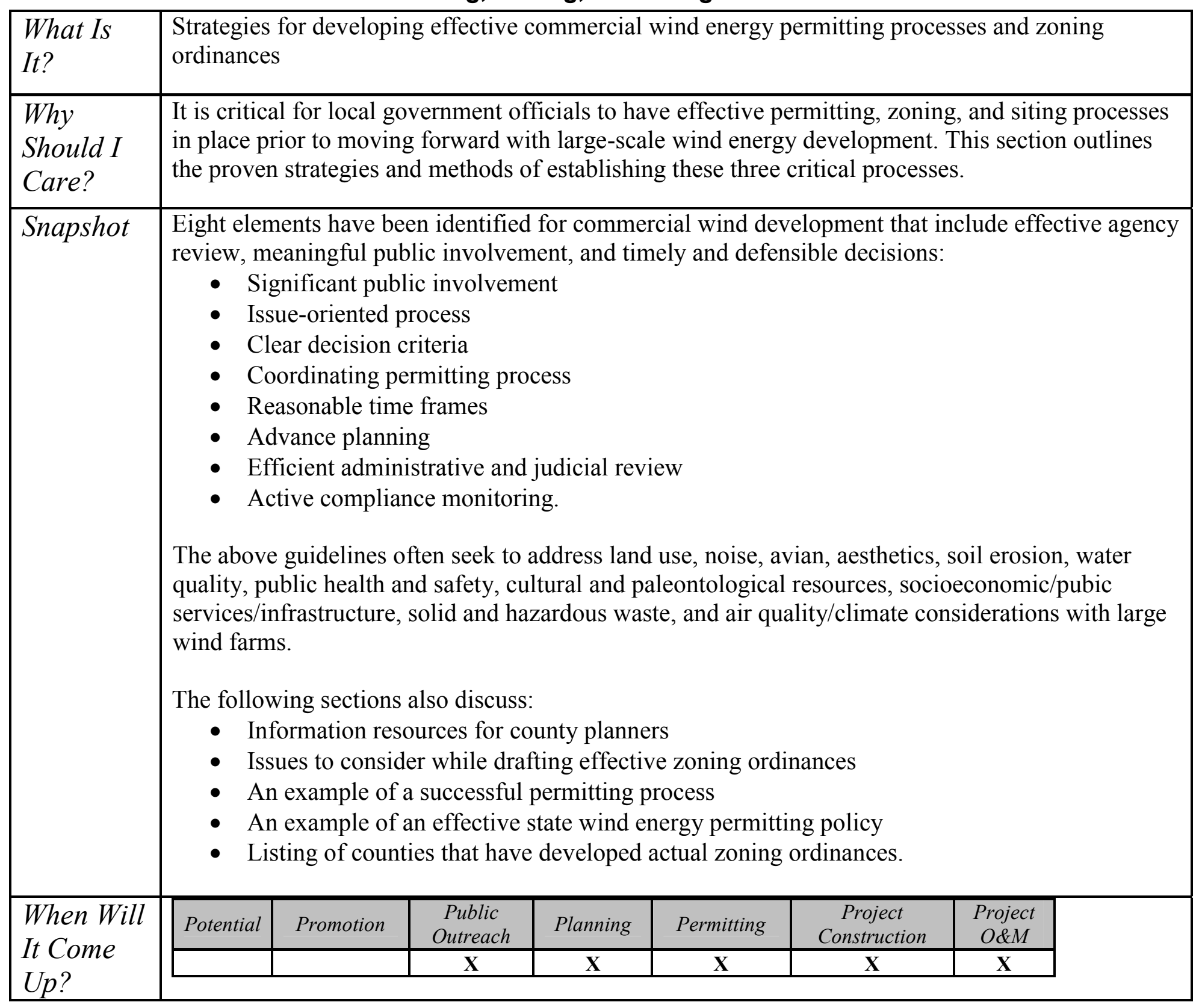




\section{Permitting, Zoning, and Siting Processes, cont.}

\begin{tabular}{|c|c|c|}
\hline 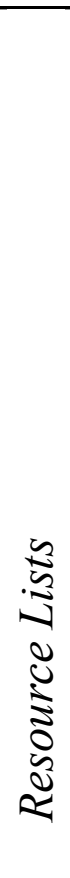 & & $\begin{array}{l}\text { "Permitting of Wind Energy Facilities-a Handbook," National Wind Coordinating Committee, } \\
\text { http://nationalwind.org/publications/siting/permitting2002.pdf. This document is the source for } \\
\text { effective methods and strategies for permitting wind projects. The handbook is written for individuals } \\
\text { and groups involved in evaluating wind projects, including decision-makers and agency staff at all } \\
\text { levels of government, wind developers, interested parties, and the public. Its purpose it to assist } \\
\text { stakeholders to be informed participates in the wind energy development decision-making process. } \\
\text { Topics include an overview of wind development and permitting, guidelines for structuring the wind } \\
\text { farm permitting process, specific permitting considerations and strategies, and case studies. } \\
\text { "Planning and Zoning for Wind Power Facilities," American Planning Association Zoning News } \\
\text { February } 2003 \text { article. A great resource for local planners, the article examines siting criteria and major } \\
\text { impacts of wind turbines in the context of local planning and zoning. Unlike natural gas or coal- } \\
\text { burning facilities, where regulation occurs at the state level, wind power facility regulation happens } \\
\text { locally, and most states do not require permits. Any impacts that would need mitigation are generally } \\
\text { confined to a local area because wind turbines generally have no impact beyond their circumference of } \\
\text { visibility. However, state permits may be required when facilities impact wetlands, sand dunes, or } \\
\text { other sensitive environments. As with all projects, review zoning ordinance and the master plan to } \\
\text { ensure compatibility. }\end{array}$ \\
\hline & 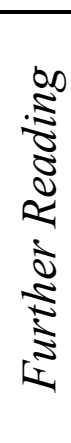 & $\begin{array}{l}\text { "Wind Turbine Siting," Minnesota Environmental Quality Board," } \\
\text { http://www.eqb.state.mn.us/EnergyFacilities/wind.html } \\
\text { "MN Model Wind Energy Conversion Ordinance - 2005," Minnesota Association of County Planning } \\
\text { and Zoning Administrators, et al., } \\
\text { http://www.mncounties3.org/macpza/Dist\%20D\%20modelwindordinancefinal.pdf } \\
\text { "Wind Turbines and Birds: Putting the Situation in Perspective in Wisconsin," Wisconsin Focus on } \\
\text { Energy, http://www.focusonenergy.com }\end{array}$ \\
\hline
\end{tabular}




\section{Case Studies}

\begin{tabular}{|c|c|c|c|c|c|c|c|c|}
\hline \multicolumn{2}{|c|}{$\begin{array}{l}\text { What IS } \\
\text { It? }\end{array}$} & \multicolumn{7}{|c|}{ Description of successful wind project case studies } \\
\hline \multicolumn{2}{|c|}{$\begin{array}{l}\text { Why } \\
\text { Should I } \\
\text { Care? }\end{array}$} & \multicolumn{7}{|c|}{$\begin{array}{l}\text { This section provides an analysis of past wind } \\
\text { work and why. }\end{array}$} \\
\hline \multicolumn{2}{|c|}{ Snapshot } & \multicolumn{7}{|c|}{$\begin{array}{l}\text { - Listen carefully to community concerns and gather information as needed. } \\
\text { - Educate the public using techniques that meaningfully communicate the results of developing } \\
\text { the site. } \\
\text { - Communicate early and often with landowners and other stakeholders. } \\
\text { - Remain open to unorthodox solutions to potential concerns; many can be mitigated with } \\
\text { effort and flexibility. } \\
\text { - Many success stories are outlined in the "Wind Power for Rural Economic Development" } \\
\text { Wind Powering America presentation. }\end{array}$} \\
\hline \multirow{2}{*}{\multicolumn{2}{|c|}{$\begin{array}{l}\text { When } \\
\text { Will It } \\
\text { Come } \\
\text { Up? }\end{array}$}} & Potential & Promotion & $\begin{array}{c}\text { Public } \\
\text { Outreach }\end{array}$ & Planning & Permitting & $\begin{array}{c}\text { Project } \\
\text { Construction }\end{array}$ & \\
\hline & & & $\underline{\mathbf{x}}$ & $\bar{x}$ & & & & \\
\hline \multirow[t]{2}{*}{ 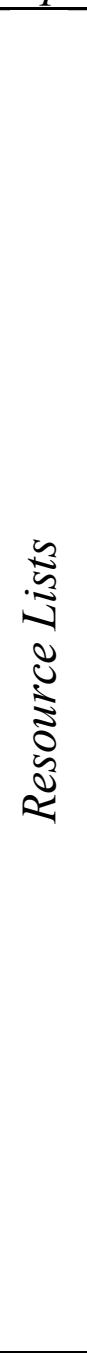 } & 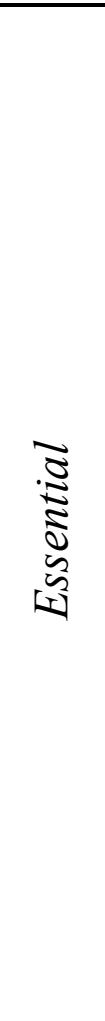 & \multicolumn{7}{|c|}{$\begin{array}{l}\text { "Wind Power Facility Siting Case Studies: Community Response," National Wind Coordinating } \\
\text { Committee, } \\
\text { http://nationalwind.org/publications/siting/Wind Power_Facility Siting_Case Studies.pdf. The } \\
\text { NWCC Siting Workgroup studied communities' reactions to local wind development projects, with } \\
\text { the intent of identifying circumstances that distinguish welcomed projects from projects that were not } \\
\text { accepted by the communities. The NWCC Siting Workgroup was also interested in examining the } \\
\text { changes in community perceptions before, during, and after project construction, as well as } \\
\text { recognizing what wind project developers can do to address the concerns that often recur at wind } \\
\text { project sites. Case studies are presented from southwestern Minnesota, central New York, and south- } \\
\text { central/western Oklahoma. The interviews and background research identified many keys to molding } \\
\text { a successful partnership among wind developers, local communities, governments, and other } \\
\text { concerned parties. The following approaches were used by developers to successfully deal with } \\
\text { community concerns: listen carefully to community concerns, educate the public, communicate early } \\
\text { and often, and remain open to unorthodox solutions. } \\
\text { "Community Owned Wind Projects: Case Studies," Windustry, } \\
\text { http://www.windustry.org/community/projects.htm. Community ownership of wind projects has } \\
\text { proven to be a powerful driver for rural economic development. When local groups own wind } \\
\text { projects, energy dollars stay local and jobs are created. This page contains information of many } \\
\text { successful projects and information about different and creative ways to structure them to maximize } \\
\text { local benefit from clean renewable energy. }\end{array}$} \\
\hline & 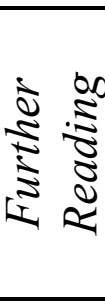 & $\begin{array}{l}\text { "Wind } \\
\text { http://v } \\
\text { windpc }\end{array}$ & or Rl & W & $\begin{array}{l}\text { opm } \\
\text { ro/ }\end{array}$ & df & 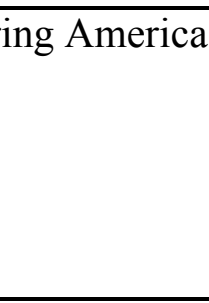 & \\
\hline
\end{tabular}




\section{Further Information}

\begin{tabular}{|c|c|c|c|c|c|c|c|}
\hline What Is It? & \multicolumn{7}{|c|}{ Additional information on topics not included in this guidebook } \\
\hline $\begin{array}{l}\text { Why Should I } \\
\text { Care? }\end{array}$ & \multicolumn{7}{|c|}{ If you have the time, you can learn more about wind energy projects. } \\
\hline \multirow{2}{*}{$\begin{array}{l}\text { When Will It } \\
\text { Come Up? }\end{array}$} & Potential & Promotion & $\begin{array}{c}\text { Public } \\
\text { Outreach }\end{array}$ & Planning & Permitting & $\begin{array}{c}\text { Project } \\
\text { Construction }\end{array}$ & $\begin{array}{c}\text { Project } \\
O \& M \\
\&\end{array}$ \\
\hline & & $\underline{x}$ & $\mathbf{X}$ & & & & \\
\hline $\begin{array}{l}\text { Further } \\
\text { Reading }\end{array}$ & $\begin{array}{l}\text { Windustry } \\
\text { www.win } \\
\text { "Windust } \\
\text { developm } \\
\text { developm } \\
\text { "Federal } \\
\text { Energy Pc } \\
\text { “America } \\
\text { Associatic } \\
\text { "Bring W } \\
\text { http://ww } \\
\text { Wind Pon } \\
\text { http://ww } \\
\text { wkshp 20 } \\
\text { "Balancin } \\
\text { Plans," La } \\
\text { http://ww } \\
\text { workshop }\end{array}$ & $\begin{array}{l}\text { Web site. } \\
\text { ustry.org } \\
\text { 's Wind Fa } \\
\text { nt discussic } \\
\text { nt, www.w } \\
\text { nergy Subs } \\
\text { icy Project } \\
\text { Planning A } \\
\text {, http://wu } \\
\text { dd Energy } \\
\text { awea.org// } \\
\text { ering Amer } \\
\text { eere.energ } \\
6 \text { state su } \\
\text { Cost \& Ri } \\
\text { vrence Berl } \\
\text { eere.energ } \\
2006 \text { sum }\end{array}$ & $\begin{array}{l}\text { tensive in } \\
\text { ners Nety } \\
\text { s where es } \\
\text { dfarmersn } \\
\text { les: Not A } \\
\text { ttp://wwy } \\
\text { sociation } \\
\text { planning } \\
\text { to Code,' } \\
\text { bs/docum } \\
\text { a State W } \\
\text { gov/wind } \\
\text { mit.asp } \\
\text { : The Tre } \\
\text { ley Natio } \\
\text { gov/wind } \\
\text { it/wiser.p }\end{array}$ & $\begin{array}{l}\text { mation fr } \\
\text { k." An or } \\
\text { erts discus } \\
\text { work.org } \\
\text { Technolo } \\
\text { epp.org/re } \\
\text { licy Guid } \\
\text { g/policyg } \\
\text { merican } \\
\text { ts/Perspe } \\
\text { W Working } \\
\text { dhydro/w } \\
\text { nent of W } \\
\text { Laboratc } \\
\text { dhydro/w }\end{array}$ & 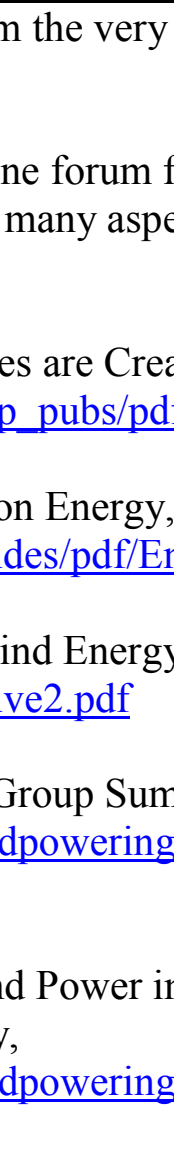 & $\begin{array}{l}\text { ic to the ver } \\
\text { vind energy } \\
\text { of wind ene } \\
\text { Equal," Re1 } \\
\text { bsidies.pdf } \\
\text { merican Pla } \\
\text { y.pdf } \\
\text { sociation, } \\
\text { erica/ } \\
\text { estern Utilit } \\
\text { erica/pdfs/ }\end{array}$ & $\begin{array}{l}\text { vable } \\
\text { ng }\end{array}$ \\
\hline
\end{tabular}




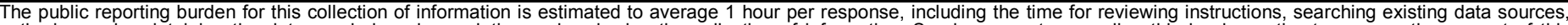

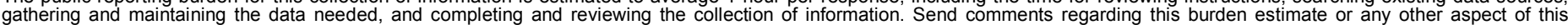

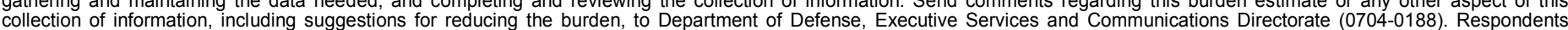

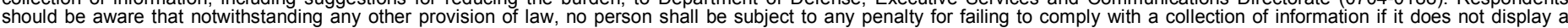

should be aware that notwithstanding

PLEASE DO NOT RETURN YOUR FORM TO THE ABOVE ORGANIZATION.

\begin{tabular}{|c|c|}
\hline $\begin{array}{l}\text { 1. REPORT DATE (DD-MM-YYYY) } \\
\text { October } 2006\end{array}$ & 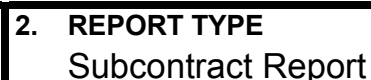 \\
\hline
\end{tabular}

4. TITLE AND SUBTITLE

Wind Energy Guide for County Commissioners

3. DATES COVERED (From - To)

June 17, 2005 - June 30, 2006

5a. CONTRACT NUMBER

DE-AC36-99-G010337

5b. GRANT NUMBER

5c. PROGRAM ELEMENT NUMBER

6. AUTHOR(S)

M. Costanti 5d. PROJECT NUMBER

NREL/SR-500-40403

5e. TASK NUMBER

WER6 6006

5f. WORK UNIT NUMBER
7. PERFORMING ORGANIZATION NAME(S) AND ADDRESS(ES)

Michael Costanti

Salient Energy Inc.

202 South Black Ave., Suite 505

Bozeman, MT 59715

9. SPONSORING/MONITORING AGENCY NAME(S) AND ADDRESS(ES)

National Renewable Energy Laboratory;1617 Cole Blvd.; Golden, CO

80401-3393

U.S. Department of Energy; 1000 Independence Ave., SW; Washington, DC 20585
8. PERFORMING ORGANIZATION REPORT NUMBER

LEE-5-558890-01

\section{DISTRIBUTION AVAILABILITY STATEMENT}

National Technical Information Service

U.S. Department of Commerce

5285 Port Royal Road

Springfield, VA 22161

13. SUPPLEMENTARY NOTES

NREL Technical Monitor: L. Flowers

14. ABSTRACT (Maximum 200 Words)

One of the key stakeholders associated with economic development are local government officials, who are often required to evaluate and vote on commercial wind energy project permits, as well as to determine and articulate what wind energy benefits accrue to their counties. Often these local officials lack experience with large-scale wind energy and need to make important decisions concerning what may be a complicated and controversial issue. These decisions can be confounded with diverse perspectives from various stakeholders. This project is designed to provide county commissioners, planners, and other local county government officials with a practical overview of information required to successfully implement commercial wind energy projects in their county. The guidebook provides readers with information on the following 13 topics: Brief Wind Energy Overview; Environmental Benefits; Wind Energy Myths and Facts; Economic Development Benefits; Wind Economics; The Development Process; Public Outreach; Siting Issues; Property Tax Incentives; Power System Impacts; Permitting, Zoning, and Siting Processes; Case Studies; and Further Information. For each of the above topics, the guidebook provides an introduction that identifies the topic, why local government should care, a topic snapshot, how the topic will arise, and a list of resources that define and assess the topic.

15. SUBJECT TERMS

wind energy; county commissioners; rural economic development; wind energy projects; wind projects; wind economics; wind project development; wind project siting; wind project zoning; wind project permitting; wind project case studies.

\section{SECURITY CLASSIFICATION OF:}

\begin{tabular}{|l|l|l|}
\hline a. REPORT & b. ABSTRACT & c. THIS PAGE \\
Unclassified & Unclassified & Unclassified \\
\hline
\end{tabular}

\begin{tabular}{|c|c|}
\hline $\begin{array}{l}\text { 17. LIMITATION } \\
\text { OF ABSTRACT }\end{array}$ & $\begin{array}{l}\text { 18. } \\
\text { NUMBER } \\
\text { OF PAGES }\end{array}$ \\
\hline UL & \\
\hline
\end{tabular}

19a. NAME OF RESPONSIBLE PERSON

19b. TELEPHONE NUMBER (Include area code) 
For more information contact:

EERE Information Center

1-877-EERE-INF (1-877-337-3463)

www.eere.energy.gov

\section{A Strong Energy Portfolio for a Strong America}

Energy efficiency and clean, renewable energy will mean a stronger economy, a cleaner environment, and greater energy independence for America. Working with a wide array of state, community, industry, and university partners, the U.S. Department of Energy's Office of Energy Efficiency and Renewable Energy invests in a diverse portfolio of energy technologies.

Produced for the U.S. Department of Energy by the National Renewable Energy Laboratory, a DOE national laboratory

DOE/G0-102006-2370 • October 2006

Printed with a renewable-source ink on paper containing at least $50 \%$ wastepaper, including $10 \%$ postconsumer waste. 